\title{
Profil Penderita Endometriosis di RSUP Prof. Dr. R. D. Kandou Manado pada Tahun 2011-2015
}

\author{
${ }^{1}$ Grandy Pangemanan \\ ${ }^{2}$ Maria Loho \\ ${ }^{2}$ Freddy W. Wagey
}

\author{
${ }^{1}$ Kandidat Skripsi Fakultas Kedokteran Universitas Sam Ratulangi Manado \\ ${ }^{2}$ Bagian Obstetri dan Ginekologi Fakultas Kedokteran \\ Universitas Sam Ratulangi Manado \\ Email: grandypangemanan12034@gmail.com
}

\begin{abstract}
Endometriosis is a benign gynecological disorder that often affects woman of reproductive age are characterized by the presence of endometrial glands and stroma outside the normal location. The disease gets a lot of attention from researchers and experts; this is due to that endometriosis often occurs in woman but the mechanism in still unclear. This was a descriptive retrospective study using the medical records of cases in Obstetric and Gynecology Department at Prof. Dr. R. D. Kandou Hospital Manado 2011 - 2015. The results showed that there were 33 cases of endometriosis during that period. The most frequent cares were $\geq 39$ years old $(39,3 \%)$, nulliparous $(36,3 \%)$, complaint of abdominal pain $(81,8 \%)$, and most types of endometriosis was ovarian endometrial cyst $(78,8 \%)$. Treatment given was medical therapy and operation.
\end{abstract}

Keywords: endometriosis

\begin{abstract}
Abstrak: Endometriosis merupakan kelainan ginekologik jinak yang sering diderita oleh perempuan usia reproduksi yang ditandai dengan adanya glandula dan stroma endometrium di luar letak normal. Penyakit ini makin mendapat perhatian dari para peneliti dikarenakan endometriosis makin sering terjadi pada wanita namun belum diketahui mekanisme yang jelas tentang terjadinya penyakit ini. Penelitian ini bertujuan untuk mengetahui profil penderita endometriosis yang dirawat di RSUP Prof. Dr. R. D. Kandou Manado. Penelitian ini bersifat deskriptif retrospektif dengan menggunakan catatan rekam medik dengan subjek penelitian ialah semua kasus di bagian obstetric dan ginekologi RSUP Prof. Dr. R. D. Kandou Manado pada tahun 2011-2015. Hasil penelitian memperlihatkan 33 kasus endometriosis dengan distribusi terbanyak menurut kelompok umur $\geq 39(39,3 \%)$, nulipara $(36,3 \%)$. Keluhan nyeri perut $(81,8 \%)$. Jenis endometriosis terbanyak adalah ovarian endometrial cyst $(78,8 \%)$. Penanganan yang diberikan berupa terapi medikamentosa dan operasi.
\end{abstract}

Kata kunci: endometriosis

Endometriosis uteri adalah suatu keadaan di mana jaringan endometrium yang masih berfungsi terdapat di luar kavum uteri. Jaringan ini yang terdiri atas kelenjarkelenjar dan stroma terdapat di dalam myometrium ataupun di luar uterus, bila jaringan endometrium terdapat di dalam miometrium disebut adenomiosis. Endo- metriosis paling sering ditemukan pada perempuan melahirkan di atas usia 30 tahun disertai dengan gejala menoragia dan dismenore yang progresif. Kejadian adenomiosis bervariasi antara $8-40 \%$ dijumpai pada pemeriksaan dari semua spesimen histerektomi. Dari 30\% pasien ini diketemukan adanya endometriosis dalam 
rongga peritoneum secara bersamaan. ${ }^{1}$

Angka kejadiannya berkisar 13,6$69,5 \%$ pada kelompok infertilitas. Pada pasangan infertil dijumpai 25\% diakibatkan oleh endometriosis, sedangkan pada kasus infertilitas idiopatik penyakit ini dijumpai $80 \%{ }^{2}$

The Endometriosis Association Research Registry melakukan penelitian retrospektif terhadap 3020 kasus endometriosis dan menemukan 2-4\% pada usia reproduksi, $40.6 \%$ di usia $<20$ tahun, $42.9 \%$ di usia $20-29$ tahun dan $16.5 \%$ pada usia 30-39 tahun. Usia rata-rata penderita endometriosis adalah 25-35 tahun dan jarang pada pasca menopause. Sampai saat ini mekanisme terjadinya endometriosis belum dapat diketahui secara pasti. Terdapat beberapa teori penyebab endometriosis yang dinyatakan oleh para ahli sebagai berikut: ${ }^{3}$ metaplasia, menstruasi mundur, predisposisi genetik, pengaruh lingkungan, serta teori emboli limfatik dan vaskular. Faktor risiko endometriosis ialah wanita yang ibu atau saudara perempuannya pernah menderita endometriosis, memiliki siklus menstruasi kurang atau lebih dari 27 hari, menarke pada usia relatif muda ( $<11$ tahun), masa menstruasi berlangsung selama 7 hari atau lebih. ${ }^{4}$

Endometriosis dapat tumbuh dimana saja di dalam pelvis dan pada permukaan peritoneum ekstrapelvis lainnya. Ovarium, peritoneum pelvis cul-desac anterior dan posterior, dan ligamen uterosakral merupakan area yang paling sering terlibat pada kasus endometriosis. Selain beberapa area tersebut, septum retrovaginal, ureter, kandung kemih, perikardium, bekas luka bedah, dan pleura juga dapat menjadi lokasi endometriosis. Sebuah studi mengungkapkan bahwa endometriosis telah ditemukan pada seluruh organ, kecuali pada limpa. Beberapa lokasi anatomis endometriosis ialah: endometriosis uteri interna (adenomiosis uteri), ovarium, tuba, retroservikalis, dan ekstra vagina. ${ }^{5}$

Gejala endometriosis menurut American Fertility Society berupa nyeri haid: Banyak wanita mengalami nyeri pada saat haid normal. Bila nyeri dirasakan berat maka disebut dysmenorrhea dan mungkin menjadi penyebab endometriosis atau tipe lain dalam patologi pelvik seperti uteri fibroid atau adenomiosis. Nyeri berat juga dapat menyebabkan mual-mual, muntah, dan diare. Dysmenorrhea primer terjadi saat awal terjadinya menstruasi, kemudian cenderung meningkat selama masa reproduktif atau setelah masa reproduktif. Dysmenorrhea sekunder terjadi setalah kehidupan selanjutnya dan mungkin akan terus meningkat dengan umur. Ini mungkin menjadi sebuah tanda peringatan dari endometriosis, walaupun beberapa wanita dengan endometriosis tidak merasa nyeri. ${ }^{6}$ Nyeri saat berhubungan pada endometriosis dapat menyebabkan rasa nyeri selama dan setelah berhubungan, kondisi ini diketahui sebagai dysparenuria. Penetrasi dalam dapat menghasilkan rasa nyeri di batasan ovarium dengan jaringan otot di bagian atas vagina. Rasa nyeri disebabkan adanya nodul lunak endometriosis di belakang uterus atau pada ligamen, yang berhubungan dengan serviks. Nyeri pelvis sering ditemukan pada pasien endometriosis, beberapa kasus nyeri pada pasien tidak hanya dikaitkan dengan periode menstruasi atau aktifitasi seksual, tetapi seringkali nyeri yang dirasakan merupakan nyeri yang kronik dan rasa tidak nyaman pada bagian bawah pelvis disertai nyeri yang terusmenerus. Nyeri pada pelvis dihubungkan dengan adanya adhesi dan ditemukannya jaringan parut pada pelvis. Penyebab yang pasti pada nyeri masih belum jelas, namun adanya substansi sitokin dan prostaglandin yang dihasilkan oleh implan endometriotik ke cairan peritoneal merupakan salah satu penyebab. Nyeri punggung bawah pda endometriosis yang terjadi pada ligament uterosacral dapat menghasilkan nyeri yang menjalar hingga ke punggung bagian belakang. Nyeri dari uterus juga dapat menjalar ke area tersebut. ${ }^{7}$

Pemeriksaan yang dilakukan untuk menegakkan diagnosis endometriosis ialah: ultrasonografi (USG), magnetic resonance imaging (MRI), pemeriksaan serum CA 125 , bedah laparaskopi, dan pemeriksaan patologi anatomi. ${ }^{8,9}$ 


\section{METODE PENELITIAN}

Jenis penelitian ini ialah deskriptif retrospektif, dengan cara mengumpulkan data rekam medik pasien endometriosis. Penelitian ini dilaksanakan pada bulan Oktober 2015 sampai bulan Dsember 2015 di bagian Obstetri dan Ginekologi RSUP Prof. Dr. R. D. Kandou Manado. Populasi penelitian ialah seluruh pasien endometriosis yang dirawat di RSUP Prof. Dr. R. D. Kandou Manado tahun 2011- 2015. Variabel penelitian ialah umur, pendidikan, keluhan dismenore, paritas, jenis endometriosis, lokasi, dan penanganan.

\section{HASIL PENELITIAN}

Berdasarkan penelitian yang dilakukan dibagian Obstetri dan Ginekologi RSUP Prof. R. D. Kandou Manado pada periode tahun 2011-2015 terdapat 33 wanita yang menderita Endometriosis dengan data sebagai berikut.

Tabel 1 menunjukkan karakteristik pasien endometriosis berdasarkan usia, paritas, dan pendidikan. Pasien terbanyak yaitu berusia $\geq 39$ tahun, yaitu berjumlah 13 orang $(39,3 \%)$ dan yang paling sedikit terjadi pada usia $\leq 20$ tahun, yaitu berjumlah 1 orang (3,03\%). Angka kejadian pada pasien nulipara sebanyak 12 orang $(36,3 \%)$, pada pasien primara sebanyak 11 orang $(33,3 \%)$, sedangkan pada pasien multipara sebanyak 10 orang $(30,3 \%)$. Menurut pendidikan sebanyak 1 orang $(3,03 \%)$ bependidikan SD, 2 orang $(6,06 \%)$ berpendidikan SMP, 14 orang $(42,4 \%)$ berpendidikan SMA, 1 orang $(3,03 \%)$ berpendidikan D3, dan 2 orang $(6,06 \%)$ berpendidikan S1.

Tabel 2 menggambarkan keluhan penderita endometriosis. Dari data yang didapatkan sebanyak 31 orang $(93,3 \%)$ mengalami nyeri haid, 6 orang $(18,1 \%)$ mengalami nyeri saat BAK, 3 orang $(9,09 \%)$ mengalami nyeri $\mathrm{BAB}, 29$ orang $(87,8 \%)$ mengalami nyeri perut, 7 orang $(21,2 \%)$ mengalami nyeri punggung, 1 orang $(3,03 \%)$ mengalami benjolan inguinal, dan 7 orang $(21,2 \%)$ mengalami perdarahan iregular.
Tabel 1. Jumlah dan persentase penderita endometriosis berdasarkan usia, paritas dan pendidikan

\begin{tabular}{ccc}
\hline Karakteristik & \multicolumn{2}{c}{ Jumlah } \\
\cline { 2 - 3 } & $\mathrm{N}$ & $\%$ \\
\hline Usia & 1 & $3,03 \%$ \\
$<20$ & 7 & $21,2 \%$ \\
$20-29$ & 12 & $36,3 \%$ \\
$30-39$ & 13 & $39,3 \%$ \\
$>39$ & 33 & \\
Jumlah & & \\
Paritas & 12 & $36,3 \%$ \\
Nulipara $\left(\mathrm{P}_{0}\right)$ & 11 & $33,3 \%$ \\
Primipara $\left(\mathrm{P}_{1}\right)$ & 10 & $30,3 \%$ \\
Multipara $\left(\mathrm{P}_{2}\right)$ & 33 & \\
Jumlah & & \\
\hline Pendidikan & 1 & $3,03 \%$ \\
SD & 2 & $6,06 \%$ \\
SMP & 14 & $42,4 \%$ \\
SMA & 1 & $3,03 \%$ \\
D3 & 2 & $6,06 \%$ \\
S1 & 13 & \\
Tidak ada & & \\
Jumlah & 33 & \\
\hline
\end{tabular}

Tabel 2. Jumlah dan persentase penderita endometriosis berdasarkan keluhan

\begin{tabular}{lcc}
\hline \multirow{2}{*}{\multicolumn{1}{c}{ Keluhan }} & \multicolumn{2}{c}{ Jumlah } \\
\cline { 2 - 3 } & $\mathrm{N}$ & $\%$ \\
\hline Nyeri haid & 31 & $93,9 \%$ \\
Nyeri saat BAK & 6 & $18,1 \%$ \\
Nyeri saat BAB & 3 & $9,09 \%$ \\
Nyeri perut & 29 & $87,8 \%$ \\
Nyeri punggung & 7 & $21,2 \%$ \\
Benjolan di inguinal & 1 & $3,03 \%$ \\
Benjolan di bekas & & \\
episiotomi & - & - \\
Perdarahan irregular & 7 & $21,2 \%$ \\
\hline
\end{tabular}

Tabel 3 menunjukkan persentase berdasarkan klinis endometriosis. Terdapat 8 orang $(24,2 \%)$ dengan adenomyosis, 8 orang $(24,2 \%)$ dengan endometriois ovarium, 1 orang $(3,03 \%)$ dengan endometriosis tuba, dan sebanyak 16 orang tidak memiliki keterangan.

Tabel 4 menggambarkan jenis endometriosis. Terdapat 26 orang $(78,8 \%)$ dengan jenis ovarian endometrial cyst dan 7 orang tidak memiliki keterangan. 
Tabel 3. Jumlah dan persentase penderita endometriosis berdasarkan klinis

\begin{tabular}{lcc}
\hline \multirow{1}{*}{ Klinis } & \multicolumn{2}{c}{ Jumlah } \\
\cline { 2 - 3 } & $\mathrm{N}$ & $\%$ \\
\hline Adenomyosis & 8 & $24,2 \%$ \\
Endometriosis ovarium & 8 & $24,2 \%$ \\
Endometriosis tuba & 1 & $3,03 \%$ \\
Endometriosis eksterna & - & - \\
Tidak ada data & 16 & \\
Jumlah & 33 & \\
\hline
\end{tabular}

Tabel 4. Jumlah dan persentase penderita endometriosis berdasarkan jenis endometriosis

\begin{tabular}{lcc}
\hline \multirow{2}{*}{ Jenis } & \multicolumn{2}{c}{ Jumlah } \\
\cline { 2 - 3 } & $\mathrm{N}$ & $\%$ \\
\hline Peritoneal endometrisis & - & - \\
Ovarian endometrial cyst & 26 & $78,8 \%$ \\
Deep nodular & - & - \\
endometriosis & & \\
Tidak ada data & 7 & \\
Jumlah & 33 \\
\hline
\end{tabular}

Tabel 5 menunjukkan hasil pemeriksaan patologi anatomi. Terdapat 2 orang $(6,06 \%)$ dengan kista cokelat ovarium bilateral, 1 orang $(3,03 \%)$ dengan kista hemoragik ovarii, dan 30 orang tidak memiliki keterangan.

Tabel 5. Jumlah dan persentase penderita endometriosis berdasarkan hasil pemeriksaan patologi anatomi

\begin{tabular}{lccc}
\hline \multicolumn{1}{c}{ Hasil PA } & & \multicolumn{2}{c}{ Jumlah } \\
\cline { 1 - 1 } $\begin{array}{l}\text { Kista cokelat ovarium } \\
\text { bilateral }\end{array}$ & & $\mathrm{N}$ & $\%, 06 \%$ \\
$\begin{array}{l}\text { Kista hemoragik ovari } \\
\text { Tidak ada data }\end{array}$ & & 1 & $3,03 \%$ \\
Jumlah & & 30 & \\
\hline
\end{tabular}

Tabel 6. Penanganan

\begin{tabular}{lcc}
\hline \multicolumn{1}{c}{ Penanganan } & \multicolumn{2}{c}{ Jumlah } \\
\cline { 2 - 3 } & $\mathrm{N}$ & $\%$ \\
\hline Operasi + medikamentosa & 21 & $63,6 \%$ \\
Medikamentosa & 11 & $33,3 \%$ \\
Tidak ada data & 1 & \\
Jumlah & 33 & \\
\hline
\end{tabular}

Tabel 6 menunjukkan penanganan yang diberikan. Sebanyak 21 orang $(63,3 \%)$ mendapat terapi operasi dan medikamen- tosa, dan 11 orang $(33,3 \%)$ hanya terapi medikamentosa, serta 1 orang tidak memiliki data.

\section{BAHASAN}

Dari hasil penelitian yang dilkukan dengan menggunakan data rekam medik dari 33 pasien endometriosis di RSUP Prof. R. D. Kandou Manado, maka diperoleh hasil sebagai berikut.

Karakterisktik usia pasien didapatkan pasien berusia 30-39 tahun berjumlah 12 orang $(36,3 \%) ; \geq 39$ tahun terdapat 13 orang $(39,3 \%) ; 20-29$ tahun yaitu 7 orang $(21,2 \%)$; dan $<20$ tahun terdapat 1 orang $(3,03 \%)$ (Tabel 1).

Umumnya pasien endometriosis berusia sekitar 25-35 tahun hal ini dikarenakan penyakit ini terjadi pada usia reproduksi. Infertilitas menjadi dampak klinik yang paling sering di jumpai, namun dari penelitian yang dilakukan di RSUP Prof. R. D. Kandou Manado, didapatkan hasil yang menunjukkan endometriosis terjadi sekitar $36,3 \%$ pada wanita nulipara, $33,3 \%$ pada wanita primipara, dan $30,3 \%$ pada wanita multipara. ${ }^{2}$ Hal ini tidak sesuai dengan penelitian Darwish et al. ${ }^{10}$ yang menyatakan bahwa paritas rendah dapat meningkatkan risiko terjadinya endometriosis. Perbedaan ini mungkin karena adanya perbedaan karakteristik responden dan adanya faktor lain yang dapat menyebabkan endometriosis seperti usia, usia menarche, panjang siklus haid, dan riwayat genetik. $^{10}$

Menurut American Fertility Society gejala endometriosis berupa nyeri haid, neri saat berhubungan, nyeri pelvis, dan neri punggung bawah. Pada penelitian yang dilakukan di RSUP Prof. Dr. R. D. Kandou terdapat sebanyak $93,9 \%$ mengalami nyeri haid, 18,1\% mengalami nyeri BAK, 9,09\% mengalami nyeri $\mathrm{BAB}, 87,8 \%$ mengalami nyeri perut, $21,2 \%$ mengalami nyeri punggung, dan 3,03\% mengalami benjolan di inguinal. Nyeri yang dirasakan penderita tergantung pada tempat terjadinya endometriosis. ${ }^{11}$

Endometriosis dapat tumbuh dimana saja di dalam pelvis maupun di permukaan 
peritoneum ekstra pelvis lainnya. Ovarium, peritoneum pelvis, cul-desac anterior dan posterior, serta ligamen uterosakral paling sering. Berdasarkan penelitian di RSUP Prof. R. D. Kandou lokasi endometriosis yang sering ditemukan terbanyak di uterus dan ovarium sebanyak $24,4 \%$ dan tuba 3,03 $\%$. Terdapat 16 orang yang mengalami endometriosis dan tidak memiliki cacatan lokasinya. $^{12}$

Berdasarkan jenis endometriosis ditemukan sebanyak $78,8 \%$ dengan jenis ovarian endometrial cyst, dan terdapat 7 orang yang tidak memiliki catatan jenis endometriosis.

Hasil dari pemeriksaan patologi anatomi memperlihatkan $6,06 \%$ dengan kista cokelat ovarium bilateral, dan 3,03\% kista hemoragik ovarii. Terdapat 30 orang tidak memiliki cacatan hasil pemeriksaan patologi anatomi.

Tabel 6 menunjukkan penanganan yang diberikan kepada pasien endomeriosis yang dilakukan di RSUP Prof. Dr. R. D. Kandou Mando yaitu pada seluruh pasien (33 orang) diberikan terapi medikamentosa untuk memperbaiki keadaan umum pasien. Didapatkan 21 orang $(63,6 \%)$ mendapat terapi operasi dan medikamentosa, dan 11 orang $(33,3 \%)$ hanya mendapat terapi medikamentosa.

\section{SIMPULAN}

Dari hasil penelitian dapat disimpulkan bahwa pasien endometriosis terbanyak pada usia $\geq 39$ tahun dengan angka kejadian terbanyak pada wanita nulipara. Keluhan terbanyak yang dijumpai ialah nyeri perut dan nyeri haid. Berdasarkan pembagian klinis, lokasi terbanyak ialah uterus (adenomiosis) dan ovarium. Pada seluruh pasien diberikan terapi medikamentosa, sebagian juga dilakukan operasi.

\section{SARAN}

Diharapkan dengan adanya penelitian ini dapat menambah pengetahuan tentang endometriosis diharapkan juga hasil penelitian dijadikan sebagai upaya promotif dan preventif bagi masyarakat agar dapat menurunkan morbiditas dan mortalitas serta meningkatkan angka harapan hidup penderita endometriosis.

Dalam pengumpulan data penulis banyak menemukan kesulitan dalam penelitian dikarenakan beberapa data tidak lengkap ke depannya diharapkan catatan rekema medik dapat diperbaiki dan dilengkapi sehingga dapat berguna bagi penelitian selanjutnya.

\section{DAFTAR PUSTAKA}

1. Berek J. Berek \& Novak's Gynecology (15th ed). Lippincott Williams \& Wilkins, 2011.

2. Prawirohardjo S. Ilmu Kebidanan (4th ed). Jakarta: PT Bina Pustaka Sarwoono Prawirohardjo, 2014.

3. Abbas S, Ihle P, Köster I, Schubert I. Prevalence and incidence of diagnosed endometriosis and risk of endometriosis in patients with endometriosis related symptoms: findings from a statutory health insurance-based cohort in Germany. Eur J Obstet Gynecol Reprod Biol. 2012;160:79-83.

4. Treloar SA, Bell TA, Nagle CM, Purdie DM, Green AC. Early menstrual characteristics associated with subsequent diagnosis of endometriosis. Am J Obstet Gynecol. 2010;202:5346.

5. Sampson JA. Peritoneal endometriosis due to menstrual dissemination of endometrial tissue into peritoneal cavity. Am J Obstet Gynecol. 2009;14:69-72.

6. Koninckx PR, Ussia A, Adamyan L, Wattiez A, Donnez J. Deep endometriosis: definition, diagnosis, and treatment. Fertil Steril. 2012; 98:564-71.

7. Acién P, Velasco I. Endometriosis: a disease that remains enigmatic. ISRN Obstet Gynecol. 2013;17:1-12.

8. Giudice LC. Clinical practice. Endometriosis. N Engl J Med. 2010;362:2389-98.

9. Vodolazkaia A, El-Aalamat Y, Popovic D, Mihalyi A, Bossuyt X, Kyama CM, et al. Evaluation of a panel of 28 biomarkers for the non-invasive diagnosis of endometriosis. Hum Reprod. 2012;27:2698-711.

10. Darwis AM, Hassanin, Sekkin A. 
Pangemanan, Loho, Wagey: Profil penderita endometriosis...

Epidemiology and risk factors associated with laparascopically typical and atypical endometriosis among Egyptian women. Departments of Obstetrics \& Gynecology Assiut and Al-Azhar Universities, Egypt, Middle East Fertility society Journal,
2006.

11. Katsikogiannis N, Tsaroucha A, Dmimakis K, Sivridis E, Simopoulus C. Rectal endometriosis causing clolonic obstruction and concurrent endometriosis of appendix: a case report. J Med Case Reports. 2011;5. 